\title{
Analisis Fundamental Terhadap Harga Saham Pada Perusahaan Tekstil Dan Garmen Yang Terdaftar Pada BEI
}

\author{
Ani Nuraini, Sakti Brata Ismaya, Agus Baharudin \\ Universitas Respati Indonesia \\ ani@urindo.ac.id
}

\begin{abstract}
ABSTRAK
Penelitian ini bertujuan untuk mengetahui hasil analisis pengaruh fundamental yang terdiri dari $C R$, TATO, DER dan ROE terhadap harga saham pada perusahaan tekstil dan garmen yang terdaftar pada Bursa Efek Indonesia periode tahun 2014 - 2017. Penelitian ini untuk mengetahui hubungan antar variabel dengan menggunakan analisis regresi data panel dengan cross section berasal dari 12 perusahaan dan time series selama 4 tahun. Berdasarkan hasil uji Chow, uji Hausman dan uji Breusch Pagan model yang terpilih di antara Common Effect, Fixed Effect dan Random Effect adalah Random Effect yang terbaik. Hasil uji signifikan menunjukkan hanya variabel TATO yang mempunyai pengaruh signifikan dan positif terhadap harga saham.
\end{abstract}

Kata Kunci : $C R$, TATO, DER, ROE, Harga Saham

\section{ABSTRACT}

This study aims to determine the results of the analysis of fundamental influences consisting of CR, TATO, $D E R$ and ROE on stock prices in textile and garment companies listed on the Indonesia Stock Exchange in the period 2014-2017. This study is to determine the relationship between variables using regression analysis panel data with cross sections originating from 12 companies and time series for 4 years. Based on the results of the Chow test, the Hausman test and the Breusch Pagan test the model chosen among the Common Effects, Fixed Effects and Random Effects is the best Random Effect. Significant test results indicate only the TATO variable has a significant and positive influence on stock prices.

Keywords : CR, TATO, DER, ROE, Stock Prices

\section{Pendahuluan}

Kecenderungan menurunnya nilai ekspor pada industri tekstil dan garmen akhir-akhir ini disebabkan persaingan ketat pasar dunia, pasar Indonesia telah dibanjiri produk impor, hal ini menyebabkan kinerja fundamental perusahaan tertekan yang diikuti aksi penjualan saham para pelaku pasar (Ayuningtyas, 2019). Sejak masuknya tekstil dari Vietnam tahun 2012 dan China, industri tekstil di Indonesia mulai tertekan selain itu adanya kenaikan upah pertahun yang menyebabkan daya saing kita menurun, dan mengakibatkan perusahaan tekstil mengalami kerugian yang berkepanjangan (Rafael, 2017).
Gambar 1. Fluktuasi ROE dan Harga Saham Tahun 2014-2017

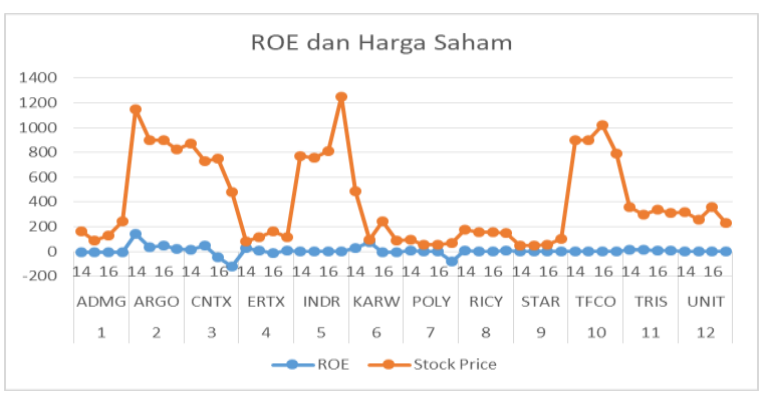

Profitabilitas yang menurun ditunjukkan oleh ROE beberapa perusahaan tekstil yang menurun dan negatif yang diikuti oleh naik turunnya harga saham. Analisis menggunakan rasio 
keuangan untuk mengeksplorasi sumber dari profitabilitas perusahaan dan mengevaluasi kualitas pendapatannya secara sistematis sebagai alat dalam mengungkap pengaruh harga saham. Pendapatan ekonomi memberikan estimasi lebih baik dibandingkan dengan pendapatan akuntansi, akan tetapi dalam praktek analis selalu menggunakan data informasi rasio keuangan perusahaan (Bodie, Zvi; Kane, Alex; Marcus, 2018).

Investor sebagai salah satu pemangku kepentingan dalam pengambilan keputusan investasinya perlu memahami analisa rasio keuangan untuk mengetahui posisi dan prospek suatu perusahaan sebagai informasi (Zutter, Chad J.; Smart, 2019). Investasi pada pasar saham berarti memperjualkan prospek perusahaan di masa mendatang, sehingga investor membutuhkan informasi dalam bentuk data keuangan yang sudah diolah (Manurung, 2012).

Penelitian ini bertujuan untuk mengetahui dan menganalisis pengaruh fundamental perusahaan pada industri tekstil dan garmen pada periode 2014 - 2017 terhadap harga saham, sehingga selanjutnya investor akan mengambil keputusan untuk membeli atau menjual sahamnya. Pasar modal saat ini merupakan pilihan untuk investasi, akan tetapi investor perlu memahami analisis fundamental perusahaan dalam menentukan pilihan sahamnya (Ou, Jane A. ; Penman, 1989). Industri yang masih merupakan andalan Indonesia adalah bidang tekstil dan garmen yang mampu menyerap tenaga kerja cukup banyak, akan tetapi akhi-akhir ini kinerjanya mulai menurun pada beberapa perusahaan dikarenakan hutang dan gagal bayar.

Analisis fundamental dalam penelitian ini terdiri dari $C R$, TATO, DER dan ROE merupakan variabel independen yang akan di analisis untuk mengetahui apakah berpengaruh terhadap harga saham. Hasil penelitian yang juga menggunakan analisis fundamental perusahaan yang terdiri dari DER, ROE, PER, dengan menambahkan suku bunga dan nilai tukar sebagai faktor makro (Djazuli, 2017). Penelitian yang sama juga dilakukan dengan analisis fundamental pada ROE, ROA dan EPS terhadap harga saham (Ilmiyono, 2019).

\section{Tinjauan Pustaka}

Teori Investasi yang dikembangkan oleh Markowitz (1952) dikenal dengan teori portofolio yang menyatakan bahwa investor melakukan investasi dengan risiko yang rendah dan mendapatkan imbal hasil yang tinggi, sehingga dilakukan investasi pada lebih dari satu instrumen investasi berupa diversifikasi risiko dengan tujuan untuk meminimalkan risiko. Teori selanjutnya adalah Capital Asset Pricing Model yang dikembangkan oleh Sharpe (1964), Lintner (1965) dan Mossin (1966) yang mempelajari tingkat pengembalian asset dipengaruhi oleh risiko saham tersebut yang lebih dikenal dengan Beta (Manurung, 2012).

Penilaian investor terhadap berhasilnya suatu perusahaan di masa yang akan datang dapat dicerminkan oleh harga saham (Brigham \& Houston, 2019). Harga saham menggambarkan semua yang berkaitan dengan masa depan perusahaan (Zutter, Chad J.; Smart, 2019). Harga saham memiliki dampak yang lebih kuat pada investasi perusahaan-perusahaan yang bergantung pada ekuitas, hal ini karena perusahaan membutuhkan ekuitas eksternal untuk membiayai tambahan investasinya (Baker, Stein, \& Wurgler, 2002).

Penentuan harga saham terdapat dua analisis yaitu analisis fundamental dan analisis teknikal (Tandelilin, 2010). Pemilihan saham terdapat dua pendekatan dasar yaitu analisis fundamental dan analisis teknikal, akan tetapi yang memperoleh perhatian cukup besar dari para analis sekuritas adalah analisis fundamental (Husnan, 2005).

Analisis fundamental yang dimaksud adalah menggunakan rasio keuangan yang terdiri dari rasio likuiditas, aktivitas, hutang, dan profitabilitas. Rasio keuangan ini akan menunjukkan kesehatan suatu perusahaan dan sebagai investor tentunya sangat penting untuk monitor investasi pada portofolio (Zutter, Chad J. ; Smart, 2019).

Analisis laporan keuangan yang menggabungkan satu rangkaian laporan keuangan ke dalam satu ukuran ringkasan yang menunjukkan arah perubahan pendapatan satu tahun ke depan. Atas dasar analisis laporan 
keuangan yang ekstensif, diperoleh ukuran ringkasan dari laporan keuangan yang memprediksi pengembalian saham di masa depan (Ou, Jane A.; Penman, 1989). Pengukuran harga saham menggunakan market price of share yaitu merupakan harga penutupan saham pada periode akhir tahun (Sharif, Purohit, \& Pillai, 2015).

Analisis fundamental dalam menentukan harga saham pada umumnya mengggunakan rasio keuangan (Tandelilin, 2010). Rasio keuangan yang terdiri dari likuiditas dalam hal ini menggunakan current ratio (CR) yang menunjukkan kemampuan perusahaan dalam memenuhi kewajibannya dalam jangka pendek, rasio aktivitas menggunakan total asset turnover (TATO) menunjukkan kemampuan setiap asset yang diinvestasikan dalam menghasilkan penjualan. Rasio hutang dengan menggunakan debt to equity ratio (DER) yang artinya mengukur proporsi relatif dari total hutang terhadap modal saham biasa yang digunakan untuk membiayai aset perusahaan, rasio profitabilitas menggunakan return on equity (ROE) yaitu mengukur tingkat pengembalian pada investasi pemegang saham biasa di perusahaan (Zutter, Chad J.; Smart, 2019).

\section{Rerangka Konsep dan Pengembangan Hipotesis}

Gambar 2. Rerangka konsep variabel

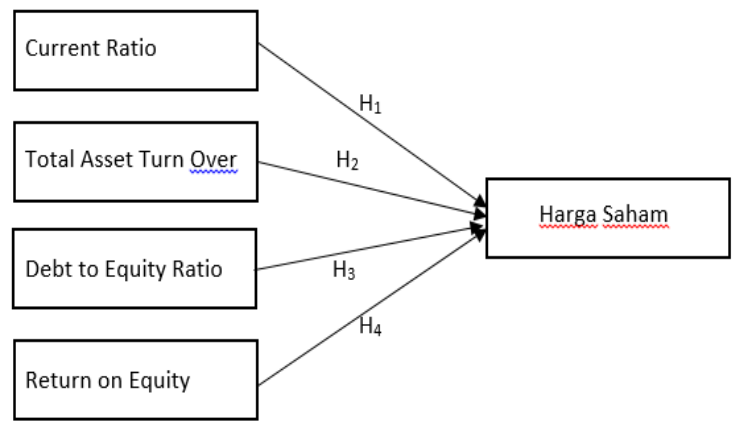

1. Pengaruh Current Ratio terhadap Harga Saham ; hasil penelitian sebelumnya menunjukkan hasil bahwa Current Ratio berpengaruh signifikan terhadap Harga Saham (Bagherzadeh, Safania, \& Roohi, 2013), akan tetapi beberapa penelitian hasilnya Current Ratio tidak signifikan (Christina, 2018), (Dewi, 2018). Berdasarkan penelitian sebelumnya, dikembangkan hipotesis penelitian $\mathrm{H}_{1}$ : Current Ratio berpengaruh terhadap Harga Saham.

2. Pengaruh Total Asset Turn Over terhadap Harga Saham, dari hasil penelitian sebelumnya menyimpulkan bahwa Total Asset Turn Over berpengaruh signifikan terhadap Harga Saham (Dewi, 2018), (Adipalguna \& Suarjaya, 2016), hasil penelitian lain menunjukkan hasil yang tidak signifikan (Asmirantho \& Somantri, 2017). Berdasarkan penelitian sebelumnya, maka dikembangkan hipotesis penelitian $\mathrm{H}_{2}$ : Total Asset Turn Over berpengaruh terhadap Harga Saham.

3. Pengaruh Debt to Equity Ratio terhadap Harga Saham, hasil penelitian menyimpulkan bahwa Debt to Equity Ratio berpengaruh signifikan (Haryanti \& Murtiasih, 2019), (Djazuli, 2017) dan hasil penelitian juga ada yang menunjukkan tidak signifikan (Christina, 2018), (Dewi, 2018). Berdasarkan penelitian sebelumnya, maka dikembangkan hipotesis penelitian $\mathrm{H}_{3}$ : Debt to Equity Ratio berpengaruh terhadap Harga Saham.

4. Pengaruh Return on Equity terhadap Harga Saham, ditunjukkan oleh penelitian sebelumnya dengan hasil signifikan antara ROE terhadap harga saham (Sharif et al., 2015), (Handayani \& Rahayu, 2019), (Christina, 2018), (Dewi, 2018), sedangkan hasil yang tidak signifikan disampaikan oleh (Puspitaningtyas, 2017). Berdasarkan penelitian sebelumnya, maka dikembangkan hipotesis $\mathrm{H}_{4}$ : Return on Equity berpengaruh terhadap Harga Saham.

\section{Metodologi}

Jenis penelitian yang digunakan dalam penelitian ini adalah kuantitatif dengan menguji pengaruh variabel bebas terhadap variabel terikat. Data yang digunakan berupa data sekunder dari Bursa Efek Indonesia dengan periode tahun 2014 - 2017 pada industri tekstil dan garmen, data yang digunakan adalah penggabungan antara data cross section dan time series yang disebut data panel karena merupakan pooling (Ekananda, 2015).

Variabel terikat dalam penelitian ini adalah $Y$, sedangkan variabel bebas terdiri dari $X_{1}, X_{2}, X_{3}$, 
dan $\mathrm{X}_{4}$. Kriteria sampel yang digunakan dalam penelitian adalah data yang tersedia pada industri tekstil dan garmen yang terdaftar pada BEl pada periode 2014 - 2017 yang mempunyai data keuangan secara lengkap sesuai dengan variabel-variabel yang digunakan dalam penelitian.

Pengukuran masing-masing variabel diproksikan sebagai berikut :

Variabel terikat :

$\mathrm{Y}=$ Harga Saham

Variabel bebas :

$\mathrm{X}_{1}=$ Current Ratio $(\mathrm{CR})$

$\mathrm{X}_{2}=$ Total Asset Turn Over (TATO)

$X_{3}=$ Debt to Equity Ratio (DER)

$\mathrm{X}_{4}=$ Return on Equity (ROE)

\begin{tabular}{|l}
\hline CR $=\frac{\text { Aktiva Lancar }}{\text { Hutang Lancar }}$ \\
\hline TATO $=\frac{\text { Penjualan }}{\text { Total Aktiva }}$ \\
DER $=\frac{\text { Total Hutang }}{\text { Modal Saham }}$ \\
\hline ROE $=\frac{\text { Laba Bersih }}{\text { Modal Saham }}$ \\
\hline
\end{tabular}

Harga Saham = Harga Penutupan Saham

Model regresi :

$H S h=\beta_{0}+\beta_{1} C R+\beta_{2}$ TATO $+\beta_{3} D E R+\beta_{4}$ ROE $+€_{i}$

Dimana :

Variabel terikat : Harga Saham (HSh)

Variabel bebas : CR, TATO, DER dan ROE

Hasil estimasi diperoleh dengan melakukan regresi data panel pada tiga model yang terdiri dari common effect model yaitu koefisien tetap antar waktu dan individu, fixed effect model yaitu slope konstan tetapi intersep berbeda antar individu dan random effect model yaitu variabel gangguan mungkin saling berhubungan antar waktu dan antar individu dimana sampel dipilih secara random yang merupakan wakil populasi, pemilihan model terbaik digunakan uji Chow, uji Hausman dan uji Lagrange Multiplier (Breusch-Pagan) (Widarjono, 2016).

Uji asumsi klasik dilakukan untuk menentukan ada tidaknya pelanggaran yang terjadi dalam regresi OLS sehingga akan menghasilkan estimasi yang baik. Uji hipotesis ditentukan dengan tingkat signifikansi koefisien regresi menggunakan uji $t$, selanjutnya uji $F$ untuk menguji signifikansi model dan uji hipotesis gabungan koefisien regresi. Koefisien Determinasi digunakan untuk mengetahui seberapa besar kemampuan vairiabel bebas dalam menjelaskan variabel terikat (Gujarati, Damodar N. ; Porter, 2010).

\section{Hasil dan Pembahasan}

Berdasarkan sampel dari data industri tekstil dan garmen maka ada 12 obyek penelitian berupa data perusahaan dengan periode penelitian 4 tahun (2014 - 2017) sehingga jumlah observasi sebesar 48, adapun data perusahaan terdiri dari :

Tabel 1. Data Perusahaan Industri Tekstil dan Garmen yang Terdaftar pada Bursa Efek Indonesia

\begin{tabular}{|c|l|c|c|l|c|}
\hline No. & \multicolumn{1}{|c|}{ Perusahaan } & Kode & No. & \multicolumn{1}{|c|}{ Perusahaan } & Kode \\
\hline 1 & Polychem Indonesia Tbk. & ADMG & 7 & Asia Pacific Fibers Tbk. & POLY \\
\hline 2 & Argo Pantes Tbk. & ARGO & 8 & Ricky Putra Globalindo Tbk. & RICY \\
\hline 3 & Century Textile Industry Tbk. & CNTX & 9 & Star Petrochem Tbk. & STAR \\
\hline 4 & Eratex Djaja Tbk. & ERTX & 10 & Tifico Fiber Indonesia Tbk. & TFCO \\
\hline 5 & Indo-Rama Synthetics Tbk. & INDR & 11 & Trisula International Tbk. & TRIS \\
\hline 6 & ICTSI Jasa Prima Tbk. & KARW & 12 & Nusantara Inti Corpora Tbk. & UNIT \\
\hline
\end{tabular}

Tabel 2. Analisis Deskriptif 


$\begin{array}{lccccc} & & & & & \\ & \text { CR } & \text { TATO } & \text { DER } & \text { ROE } & \text { E_PRIC } \\ \text { Mean } & 119.3519 & 2.311767 & 2.638333 & 4.561458 & 405.4375 \\ \text { Median } & 111.2200 & 1.287428 & 0.635000 & 1.220000 & 253.0000 \\ \text { Maximum } & 338.5300 & 20.70742 & 85.87000 & 139.7700 & 1250.000 \\ \text { Minimum } & 3.680000 & 0.552182 & -7.720000 & -122.7600 & 50.00000 \\ \text { Std. Dev. } & 92.05406 & 3.111271 & 12.86531 & 34.68668 & 354.2150 \\ \text { Skewness } & 0.624927 & 4.536720 & 5.828910 & 0.140820 & 0.763901 \\ \text { Kurtosis } & 2.523664 & 26.77957 & 38.12203 & 10.26090 & 2.177996 \\ & & & & & \\ \text { Jarque-Bera } & 3.578063 & 1295.591 & 2738.923 & 105.6001 & 6.019733 \\ \text { Probability } & 0.167122 & 0.000000 & 0.000000 & 0.000000 & 0.049298 \\ & & & & & \\ \text { Sum } & 5728.890 & 110.9648 & 126.6400 & 218.9500 & 19461.00 \\ \text { Sum Sq. Dev. } & 398275.7 & 454.9604 & 7779.262 & 56548.78 & 5897010 . \\ & & & & & \\ \text { Observations } & 48 & 48 & 48 & 48 & 48\end{array}$

Hasil statistik deskriptif menunjukkan bahwa Probabilitas Jarque-Bera angka $<0.05$ pada TATO, DER, ROE dan Harga Saham yang artinya data tidak terdistribusi normal, sedangkan pada CR probabilitas > 0.05 yang berarti data terdistribusi normal. Pengujian selanjutnya adalah effect model untuk menentukan model yang paling baik, adalah sebagai berikut :

\section{Tabel 3. Uji Common Effect Model}

\begin{tabular}{|c|c|c|c|c|}
\hline \multicolumn{5}{|c|}{$\begin{array}{l}\text { Dependent Variable: LOGY } \\
\text { Method: Panel Least Squares } \\
\text { Date: } 05 / 07 / 20 \text { Time: } 10: 40 \\
\text { Sample: } 20142017 \\
\text { Periods included: } 4 \\
\text { Cross-sections included: } 12 \\
\text { Total panel (balanced) observations: } 48\end{array}$} \\
\hline Variable & Coefficient & Std. Error & t-Statistic & Prob. \\
\hline C & 5.295165 & 0.296378 & 17.86623 & 0.0000 \\
\hline $\mathrm{X} 1$ & 0.001116 & 0.001639 & 0.680552 & 0.4998 \\
\hline $\mathrm{X} 2$ & -0.001889 & 0.048122 & -0.039247 & 0.9689 \\
\hline $\mathrm{X} 3$ & 0.029563 & 0.014334 & 2.062385 & 0.0452 \\
\hline $\mathrm{X}_{4}$ & 0.012337 & 0.005345 & 2.308120 & 0.0259 \\
\hline R-squared & 0.123263 & \multirow{7}{*}{\multicolumn{2}{|c|}{$\begin{array}{l}\text { Mean dependent var } \\
\text { S.D. dependent var } \\
\text { Akaike info criterion } \\
\text { Schwarz criterion } \\
\text { Hannan-Quinn criter. } \\
\text { Durbin-Watson stat }\end{array}$}} & 5.558221 \\
\hline Adjusted R-squared & 0.041706 & & & 1.010175 \\
\hline S.E. of regression & 0.988886 & & & 2.913857 \\
\hline Sum squared resid & 42.04949 & & & 3.108773 \\
\hline Log likelihood & -64.93256 & & & 2.987516 \\
\hline F-statistic & 1.511370 & & & 0.621998 \\
\hline Prob(F-statistic) & 0.215776 & & & \\
\hline
\end{tabular}

Hasil menunjukkan nilai signifikan pada variabel $X_{3}$ dan $X_{4}$ yaitu DER dan ROE berpengaruh positif terhadap harga saham, yang ditunjukkan oleh nilai $p$-value $<0.05$.
Tabel 4. Uji Fixed Effect Model

\begin{tabular}{|c|c|c|c|c|}
\hline $\begin{array}{l}\text { Dependent Variable: } \\
\text { Method: Panel Least } \\
\text { Date: 05/07/20 Time } \\
\text { Sample: } 20142017 \\
\text { Periods included: } 4 \\
\text { Cross-sections inclu } \\
\text { Total panel (balancec }\end{array}$ & $\begin{array}{l}\text { GY } \\
\text { uares } \\
0: 44\end{array}$ & & & \\
\hline Variable & Coefficient & Std. Error & t-Statistic & Prob. \\
\hline C & 5.347186 & 0.204240 & 26.18092 & 0.0000 \\
\hline $\mathrm{X} 1$ & 0.000701 & 0.001658 & 0.422922 & 0.6752 \\
\hline X2 & 0.070154 & 0.019449 & 3.607137 & 0.0010 \\
\hline $\mathrm{X} 3$ & -0.010786 & 0.005774 & -1.867903 & 0.0710 \\
\hline X4 & -0.001398 & 0.001928 & -0.725345 & 0.4735 \\
\hline & Effects $\mathrm{S}$ & ification & & \\
\hline Cross-section fixed ( & my variable & & & \\
\hline R-squared & 0.946152 & Mean depen & lent var & 5.558221 \\
\hline Adjusted R-squared & 0.920910 & S.D. depenc & ent var & 1.010175 \\
\hline S.E. of regression & 0.284091 & Akaike info c & iterion & 0.582156 \\
\hline Sum squared resid & 2.582643 & Schwarz cri & erion & 1.205890 \\
\hline Log likelihood & 2.028255 & Hannan-Qui & in criter. & 0.817866 \\
\hline F-statistic & 37.48403 & Durbin-Wat & on stat & 2.827566 \\
\hline Prob(F-statistic) & 0.000000 & & & \\
\hline
\end{tabular}

Regresi pada uji fixed effect model mendapatkan hasil signifikan pada variabel $\mathrm{X}_{2}$ yaitu TATO berpengaruh positif terhadap harga saham yang ditunjukkan oleh nilai $p$-value < 0.05 .

Tabel 5. Uji Random Effect Model

\begin{tabular}{|c|c|c|c|c|}
\hline \multicolumn{5}{|c|}{$\begin{array}{l}\text { Dependent Variable: LOGY } \\
\text { Method: Panel EGLS (Cross-section random effects) } \\
\text { Date: } 05 / 07 / 20 \text { Time: } 10: 53 \\
\text { Sample: } 20142017 \\
\text { Periods included: } 4 \\
\text { Cross-sections included: } 12 \\
\text { Total panel (balanced) observations: } 48 \\
\text { Swamy and Arora estimator of component variances } \\
\end{array}$} \\
\hline Variable & Coefficient & Std. Error & t-Statistic & Prob. \\
\hline C & 5.351631 & 0.328646 & 16.28390 & 0.0000 \\
\hline $\mathrm{X} 1$ & 0.000671 & 0.001463 & 0.458737 & 0.6487 \\
\hline $\mathrm{X} 2$ & 0.066754 & 0.019195 & 3.477663 & 0.0012 \\
\hline $\mathrm{X} 3$ & -0.009012 & 0.005700 & -1.580996 & 0.1212 \\
\hline $\mathrm{X} 4$ & -0.000893 & 0.001911 & -0.467203 & 0.6427 \\
\hline \multicolumn{5}{|c|}{ Effects Specification } \\
\hline & & & S.D. & Rho \\
\hline Cross-section randor & & & 0.943250 & 0.9168 \\
\hline Idiosyncratic random & & & 0.284091 & 0.0832 \\
\hline \multicolumn{5}{|c|}{ Weighted Statistics } \\
\hline R-squared & 0.250489 & \multirow{5}{*}{\multicolumn{2}{|c|}{$\begin{array}{l}\text { Mean dependent var } \\
\text { S.D. dependent var } \\
\text { Sum squared resid } \\
\text { Durbin-Watson stat }\end{array}$}} & 0.827688 \\
\hline Adjusted R-squared & 0.180767 & & & 0.323882 \\
\hline S.E. of regression & 0.293151 & & & 3.695306 \\
\hline F-statistic & 3.592680 & & & 2.013652 \\
\hline Prob(F-statistic) & 0.012970 & & & \\
\hline \multicolumn{5}{|c|}{ Unweighted Statistics } \\
\hline R-squared & -0.090464 & \multirow{2}{*}{\multicolumn{2}{|c|}{$\begin{array}{l}\text { Mean dependent var } \\
\text { Durbin-Watson stat }\end{array}$}} & 5.558221 \\
\hline Sum square & 52.30009 & & & 0.142276 \\
\hline
\end{tabular}


Uji random effect model mendapatkan hasil signifikan pada variabel $\mathrm{X}_{2}$ yaitu TATO berpengaruh positif terhadap harga saham, hasil ini ditunjukkan oleh nilai $p$-value $<0.05$.

Selanjutnya untuk menentukan model yang tepat di antara ketiga model tersebut di atas diperlukan uji berikutnya yang terdiri dari uji Chow untuk memilih antara Common Effect Model dan Fixed Effect Model, uji Hausman untuk memilih antara Fixed Effect Model dan Random Effect Model, dan uji Lagrange Multiplier untuk menentukan model yang tepat diantara Random Effect Model dan Common Effect Model, berikut hasil perhitungan uji model yang tepat:

Tabel 6. Uji Chow

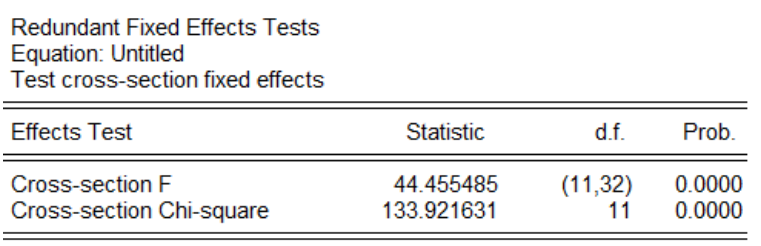

Jika $\mathrm{p}$-value $<0.05$ berarti $\mathrm{H}_{0}$ ditolak dan $\mathrm{H}_{\mathrm{a}}$ diterima, yang artinya Fixed Effect Model lebih tepat dibandingkan dengan Common Effect Model dalam pemilihan model data panel.

Tabel 7. Uji Hausman

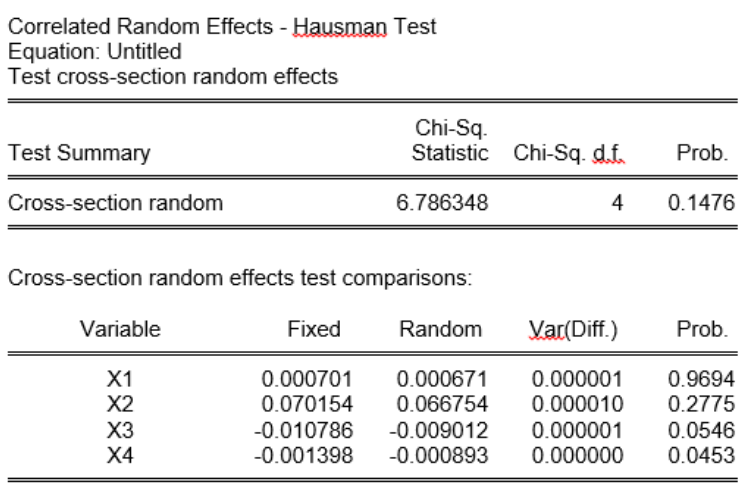

Nilai chi-squares sebesar 6,786348 dengan $p$ value sebesar 0,1476 sedangkan nilai kritis chisquares dengan $d f=4$ pada $\alpha=0.05$ sebesar 9.49 yang artinya gagal menolak $\mathrm{H}_{0}$ sehingga Random Effect Model lebih tepat dibandingkan dengan Fixed Effect Model.
Tabel 8. Uji Lagrange Multiplier

Lagrange multiplier (LM) test for panel data

Date: 05/07/20 Time: 11:05

Sample: 20142017

Total panel observations: 48

Probability in ()

\begin{tabular}{lccc}
\hline \hline $\begin{array}{l}\text { Null (no rand. effect) } \\
\text { Alternative }\end{array}$ & $\begin{array}{c}\text { Cross-section } \\
\text { One-sided }\end{array}$ & $\begin{array}{c}\text { Period } \\
\text { One-sided }\end{array}$ & Both \\
\hline \hline Breusch-Pagan & 38.49841 & 1.130407 & 39.62881 \\
Honda & $(0.0000)$ & $(0.2877)$ & $(0.0000)$ \\
& 6.204708 & -1.063206 & 3.635591 \\
King-Wu & $(0.0000)$ & $(0.8562)$ & $(0.0001)$ \\
& 6.204708 & -1.063206 & 1.929790 \\
SLM & $(0.0000)$ & $(0.8562)$ & $(0.0268)$ \\
& 7.420207 & -0.833449 & -- \\
GHM & $(0.0000)$ & $(0.7977)$ & - \\
& -- & -- & 38.49841 \\
& -- & -- & $(0.0000)$ \\
\hline \hline
\end{tabular}

Uji LM dengan menggunakan Breusch-Pagan untuk menentukan model yang tepat menghasilkan nilai $p$-value pada both sebesar $0.000<\alpha=0.05$ yang artinya menolak $\mathrm{H}_{0}$ sehingga secara signifikan Random Effect Model lebih tepat dibandingkan dengam Common Effect Model.

Analisis Regresi Berganda :

$\mathrm{HSh}=5.3516+0.0006 \mathrm{CR}+0.0667$ TATO $0.009 D E R-0.0009 R O E+\epsilon_{\mathrm{i}}$

Hasil Regresi Berganda yang digunakan untuk estimasi adalah Random Effect Model, yang merupakan hasil dari uji pemilihan model yang paling tepat. Uji asumsi klasik tidak diperlukan karena Random Effect Model estimasinya menggunakan Generalized Least Square (GLS) dimana GLS berasal dari variabel gangguan yang terdiri dari dua komponen yaitu kombinasi cross section dan time series, sehingga dapat mengatasi adanya autokorelasi runtun waktu serta korelasi antar observasi (Widarjono, 2016).

Hasil regresi pada variabel Current Ratio adalah tidak signifikan yang ditunjukkan oleh $p$-value $0.6487>0.05$ yang artinya menerima $\mathrm{H}_{0}$ yaitu Current Ratio tidak berpengaruh terhadap Harga Saham, hal ini sesuai dengan penelitian (Christina, 2018) dan (Dewi, 2018). Harga saham adalah harga yang terbentuk melalui mekanisme pasar (Sharif et al., 2015), dalam hal ini Current Ratio adalah kemampuan perusahaan dalam memenuhi kewajibannya dalam jangka pendek, maka investor tidak terlalu memperhatikan informasi jangka 
pendek, karena investor membeli saham yang berarti membeli prospek perusahaan di masa yang akan datang (Manurung, 2012).

Hasil regresi pada variabel Total Asset Turn Over memberikan hasil signifikan dengan p-value $0.0012<0.05$ artinya menolak $\mathrm{H}_{0}$ dan menerima $\mathrm{H}_{a}$ sehingga Total Asset Turn Over berpengaruh terhadap Harga Saham, hasil penelitian ini sejalan dengan penelitian (Adipalguna \& Suarjaya, 2016) dan (Dewi, 2018). Apabila Total Asset Turn Over meningkat akan berpengaruh terhadap naiknya harga saham, artinya semakin efektif perusahaan menggunakan asset nya dalam menghasilkan penjualan akan menarik investor dalam investasi sahamnya, berarti perusahaan efisien (Zutter, Chad J. ; Smart, 2019) dan mempunyai prospek yang bagus dengan menunjukkan penjualan yang baik.

Hasil regresi variabel Debt to Equity Ratio hasilnya tidak signifikan dengan $p$-value 0.1212 $>0.05$ artinya menerima $\mathrm{H}_{0}$ dan menolak $\mathrm{H}_{a}$ sehingga Debt to Equity Ratio tidak berpengaruh terhadap Harga Saham, hasil penelitian ini sejalan dengan penelitian (Christina, 2018) dan (Dewi, 2018). Catatan penting mengenai hutang ada tradeoff antara hutang yang tinggi dan hutang yang rendah dimana jika hutang tinggi akan memberikan hasil yang tinggi dan risiko juga tinggi, sedangkan berkenaan dengan metode mana yang digunakan, rasio hutang terhadap modal yang rendah sering dipandang sebagai indikasi bahwa perusahaan tidak mengambil keuntungan yang cukup dari leverage keuangan untuk meningkatkan laba (Zutter, Chad J.; Smart, 2019), hal ini memberikan persepsi yang berbeda dari para investor sehingga Debt Equity Ratio kurang begitu penting mempengaruhi harga saham.

Hasil regresi variabel Return on Equity hasilnya tidak signifikan dengan $p$-value $0.6427>0.05$ artinya menerima $\mathrm{H}_{0}$ dan menolak $\mathrm{H}_{\mathrm{a}}$ sehingga Return on Equity tidak berpengaruh terhadap Harga Saham, hasil penelitian ini sejalan dengan penelitian (Puspitaningtyas, 2017), hal ini menunjukkan bahwa ternyata investor tidak terlalu menganggap penting profitabilitas pada perusahaan yang akan memberikan imbal hasil pada sahamnya, akan tetapi mempertimbangkan risiko juga, seperti disampaikan dalam teori Capital Asset Pricing Model, bahwa harga saham dipengaruhi oleh risiko investasi tersebut (Manurung, 2012).

Nilai Adjusted $\mathrm{R}^{2}$ menunjukkan angka 0.1807 artinya kemampuan variabel bebas dalam menjelaskan variabel terikat adalah sebesar $18.07 \%$ jadi sangat kecil dan sisanya sebesar 81.93 dijelaskan oleh variabel lain di luar model penelitian, hal ini sangat rasional berdasarkan hasil uji signifikan hanya satu variabel yang signifikan yaitu variabel Total Asset Turn Over, sedangkan secara simultan $p$ value pada $\mathrm{F}$ mempunyai nilai $0.0129<0.05$ artinya signifikan mempengaruhi Harga Saham berarti $\mathrm{H}_{0}$ ditolak dan $\mathrm{H}_{\mathrm{a}}$ diterima.

Berbagai teori yang menyampaikan tentang faktor-faktor apa saja yang mempengaruhi harga saham masih perlu digali lebih banyak dan dikaji, karena ternyata analisis fundamental sudah kurang begitu penting dalam pengambilan keputusan investasi pada bidang saham, dimana selama ini analisis fundamental masih merupakan alat andalan yang dipakai oleh para analis dan praktisi dalam meramalkan harga saham untuk menentukan investasinya.

\section{Kesimpulan}

Berdasarkan tujuan penelitian yang ingin mengetahui apakah ada pengaruh analisis fundamental terhadap harga saham pada industri tekstil dan garmen, ternyata hasil nya menunjukkan bahwa hanya variabel Total Asset Turn Over, maka dengan menggunakan hal ini bisa disebabkan karena pada industri tekstil dan garmen sering terjadi informasi asimetris, hal ini ditunjukkan oleh adanya perusahaan tekstil yang tiba-tiba default tanpa diketahui oleh pemegang saham, jadi informasi kurang disampaikan secara benar kepada para pemegang saham dan berakibat pada menurunnya harga saham, sehingga pemegang saham merasa dirugikan.

Tingginya risiko yang dihadapi para investor maupun calon investor jika melakukan investasi pada industri ini dikarenakan pengaruh internal perusahaan yang kurang efisien sehingga kalah bersaing, selain itu banyaknya produk tekstil 
dan garmen yang masuk ke Indonesia, sehingga informasi sangat penting sebagai sebagai bahan pertimbangan dalam investasi saham. Selama ini investor hanya memperhatikan penjualan saja sebagai pertimbangan sesuai dengan hasil penelitian tersebut di atas.

Penelitian selanjutnya bisa di tambahkan dengan variabel yang berkaitan dengan risiko dan informasi yang ada dalam teori Capital Asset Pricing Model, Pasar Efisien, Signal serta Informasi Asimetris. Pasar saham memperjualkan prospek perusahaan di masa yang akan datang, dan harga saham akan bergerak atau berubah sesuai dengan informasi dari perusahaan.

\section{Daftar Pustaka}

1. Adipalguna, I. G. N. S., \& Suarjaya, A. A. G. (2016). PENGARUH LIKUIDITAS, SOLVABILITAS, AKTIVITAS, PROFITABILITAS, DAN PENILAIAN PASAR TERHADAP HARGA SAHAM PERUSAHAAN LQ45 DI BEI. E-Jurnal Manajemen Unud, 5(12), 7638-7668.

2. Asmirantho, E., \& Somantri, O. K. (2017). THE EFFECT OF FINANCIAL PERFORMANCE ON STOCK PRICE AT PHARMACEUTICAL SUBSECTOR COMPANY LISTED IN INDONESIA STOCK EXCHANGE. Jurnal Ilmiah Akuntansi Fakultas Ekonomi, 3(2), 94-107.

3. Ayuningtyas, D. (2019). Market : Duh! Emiten Tekstil Terpukul \& Harga Saham Anjlok. Retrieved from CNBC Indonesia website: https://www.cnbcindonesia.com/market/ 20191003123029-17-104139/duh-emitentekstil-terpukul-harga-saham-anjlok

4. Bagherzadeh, M. R., Safania, S., \& Roohi, M. (2013). Relationship between Current ratio and Share Price - a study on NSE , INDIA. Int Jr. of Mathematical Sciences \& Applications, 3(1), 163-167. Retrieved from www.journalshub.com

5. Baker, M., Stein, J. C., \& Wurgler, J. (2002). When Does The Market Matter ? Stock
Prices and The Investment of EquityDependent Firms. Massachusetts.

6. Bodie, Zvi; Kane, Alex; Marcus, A. J. (2018). Investments (Eleventh). New York: Mc Graw Hill Education.

7. Brigham, E. F., \& Houston, J. F. (2019). Fundamentals of FINANCIAL MANAGEMENT 15e. Cengage Learning.

8. Christina, O. (2018). THE EFFECT OF FINANCIAL PERFORMANCE AND FIRM SIZE ON STOCK PRICES OF MANUFACTURING COMPANY IN 2013-2016. (2007), 978-979.

9. Dewi, R. R. (2018). Effect of Financial Performance on Share Price on Listed Companies. The 2nd International Conference on Technology, Education, and Social Science 2018, 2018, 227-232.

10. Djazuli, A. (2017). The Relevance of Leverage , Profitability, Market Performance, and Macroeconomic to Stock Price. Ekonomi Bisnis, 22(2), 112122.

11. Ekananda, M. (2015). Ekonometrika Dasar (Pertama). Jakarta: Mitra Wacana Media.

12. Gujarati, Damodar N. ; Porter, D. C. (2010). Essentials of ECONOMETRICS (Fourth Edi). New York: McGraw-Hill.

13. Handayani, S. R., \& Rahayu, S. M. (2019). Stock return and financial performance as moderation variable in influence of good corporate governance towards corporate value. 4(1), 18-34. https://doi.org/10.1108/AJAR-07-20180021

14. Haryanti, Y., \& Murtiasih, S. (2019). The Effects of DER, ROA and DPR on Stock Price with EPS as the Moderating Variable in SOE. Journal of Business and Management, 21(7), 1-8. https://doi.org/10.9790/487X2107040108

15. Husnan, S. (2005). Dasar-Dasar Teori Portofolio dan Analisis Sekuritas (Keempat). Yogyakarta: UPP STIM YKPN. 
16. Ilmiyono, A. F. (2019). The Effect of ROE , ROA and EPS toward Stock Prices in Companie sub Sektor Construction and Buildings Listed in Exchange Indonesia Effect ( IDX ). International Journal of Latest Engineering and Management Research, 04(08), 24-35.

17. Manurung, A. H. (2012). Konsep dan Empiris Teori Investasi (pertama). Jakarta: PT. Adler Manurung Press.

18. Ou, Jane A. ; Penman, S. H. (1989). Financial Statement Analysis and The Prediction of Stock Returns. Jornal of Accounting and Economics, 11, 295-329. https://doi.org/https://doi.org/10.1016/0 165-4101(89)90017-7

19. Puspitaningtyas, Z. (2017). Is Financial Performance Reflected in Stock Prices? 40(Icame), 17-28.
20. Rafael, E. C. (2017). Perusahaan tekstil masih terus merugi. Retrieved from Kontan.co.id website: https://industri.kontan.co.id/news/perusa haan-tekstil-masih-terus-merugi

21. Sharif, T., Purohit, H., \& Pillai, R. (2015). Analysis of Factors Affecting Share Prices : The Case of Bahrain Stock Exchange. 7(3), 207-216. https://doi.org/10.5539/ijef.v7n3p207

22.Tandelilin, E. (2010). Portofolio dan Investasi (Pertama). Yogyakarta: PT. Kanisius.

23. Widarjono, A. (2016). Ekonometrika Pengantar dan Aplikasinya (Keempat). Yogyakarta: UPP STIM YKPN.

24. Zutter, Chad J. ; Smart, S. B. (2019). Principles of Managerial Finance (Fifteenth; C. Fenn, Ed.). United Kingdom: Pearson. 